\title{
KEDUDUKAN DAN PERAN GURU DALAM PERSPEKTIF PENDIDIKAN ISLAM
}

\author{
Hikmat Kamal \\ Hikmatkamal70@gmail.com \\ (Dosen Fakultas Agama Islam, Universitas Muhammadiyah Tangerang)
}

\begin{abstract}
Abstrak:
Pengetahuan dan keterampilan yang dikuasai guru tidak hanya terbatas pada pengetahuan yang berkaitan dengan pengembangan tugas profesional, tetapi juga tugas kemasyarakatan maupun tugas kemanusiaan. Dalam Undang-Undang Sistem Pendidikan Nasional pasal 27 ayat 3 ada tiga peranan guru yaitu:1) sebagai pengajar; 2) sebagai pembimbing; 3) sebagai administrator kelas. Peran dan kedudukan guru menyampaikan risalah kenabian kepada umat manusia, yang pada hakekatnya mengemban misi rahmatan li al 'alamin, yakni suatu misi yang mengajak umat manusia untuk tunduk dan beribadah kepada Allah SWT.
\end{abstract}

\section{Kata Kunci: Kedudukan, Peran Guru, Pendidikan Islam.}

\section{A. Pendahuluan}

Guru $^{1}$ dalam Islam ialah siapa saja yang bertanggungjawab terhadap perkembangan anak didik. ${ }^{2}$ Pendidik adalah setiap orang dewasa yang karena kewajiban agamanya bertanggung jawab atas pendidikan dirinya dan orang lain. ${ }^{3}$ Dalam Islam, orang yang paling bertanggungjawab adalah orangtua. Tanggung jawab itu disebabkan oleh dua hal yaitu pertama, karena kodrat yaitu karena orangtua ditakdirkan menjadi orangtua anaknya, dan karena itu ia ditakdirkan pula bertanggungjawab mendidik anaknya. Kedua, karena kepentingan kedua orangtua yaitu orangtua berkepentingan terhadap kemajuan perkembangan anaknya.

Kata guru berasal dalam bahasa Indonesia yang berarti orang yang mengajar. Dalam bahasa Inggris, dijumpai kata teacher yang berarti pengajar. Dalam bahasa Arab istilah al-alim (jamaknya

\footnotetext{
${ }^{1}$ Secara terminologi, guru adalah "Orang yang mendidik. (WJS. Poerwadarminta, Kamus Umum Bahasa Indonesia, (Jakarta, Gramedia, 1980), Cet ke-12, hlm. 250

${ }^{2}$ Sudiyono, Ilmu Pendidikan Islam, (Jakarta: Rineka Cipta, 2009) hlm. 110
}

ulama) atau al-mu'allim, yang berarti orang yang mengetahui dan banyak digunakan para ulama, Selain itu ada pula sebagian ulama yang menggunakan istilah almudarris untuk arti orang yang mengajar atau orang yang memberi pelajaran. Selain itu terdapat pula istilah ustadz untuk menunjuk kepada arti guru yang khusus mengajar bidang pengetahuan agama Islam. Guru adalah spiritual father (bapak rohani), bagi peserta didik yang memberikan santapan jiwa dengan ilmu, pembinaan akhlak mulia, dan meluruskan perilakunya yang buruk. Oleh karena itu, guru memiliki kedudukan tinggi. ${ }^{4}$

Sabda Nabi SAW:

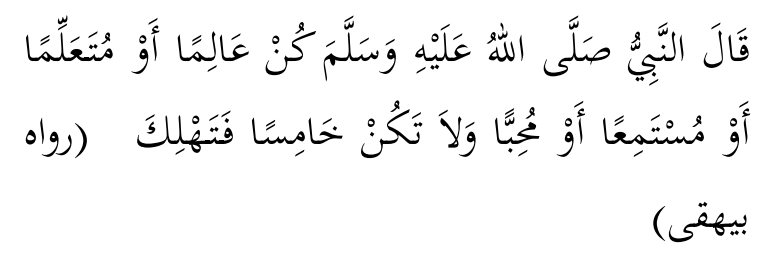

\footnotetext{
${ }^{3}$ Muhammad Muntahibun Nafis, Ilmu Pendidikan Islam, (Yogyakarta: Teras, 2011) hlm. 86

${ }^{4}$ M. Athiyah al-Abrasyi, Dasar-dasar Pokok Pendidikan Islam, Terj. Bustami A. Ghani, (Jakarta: Bulan Bintang, 1987), hlm. 135-136
} 
Nabi SAW bersabda: Jadilah engkau orang berilmu, atau orang yang menuntut ilmu, atau orang yang mau mendengarkan ilmu, atau orang yang menyukai ilmu. Dan janganlah engkau menjadi orang yang kelima maka kamu akan celaka.(HR. Baihaqi).

Dalam kitab Shahihnya, Imam AlBukhari meriwayatkan sebuah hadits dari Hajjaj bin Minhal dari Syu'bah dari Alqamah bin Martsad dari Sa'ad bin Ubaidah dari Abu Abdirrahman As-Sulami dari Utsman bin Affan Radhiyallahu Anhu, bahwa Rasulullah Shallallahu Alaihi wa Sallam bersabda:

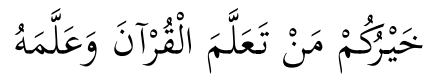

Sebaik-baik kalian adalah orang yang belajar Al-Qur'an dan mengajarkannya. (H.R. Bukhari)

Al-Ghazali menukil beberapa Hadits Nabi tentang keutamaan seorang guru. Ia berkesimpulan bahwa guru disebut sebagai orang-orang besar yang aktivitasnya lebih baik daripada ibadah setahun (perhatikan QS. At-Taubah [9]:122). Selanjutnya AlGhazali menukil dari perkataan para ulama yang menyatakan bahwa guru merupakan pelita segala zaman, orang yang hidup semasa dengannya akan memperoleh pancaran cahaya keilmiahannya. ${ }^{5}$ Di dalam UU Republik Indonesia Nomor 14 Tahun 2005 Tentang Guru Dan Dosen, disebutkan bahwa Guru mempunyai kedudukan sebagai tenaga profesional pada jenjang pendidikan dasar, pendidikan menengah, dan pendidikan anak usia dini pada jalur pendidikan formal yang diangkat sesuai dengan peraturan perundang-undangan. ${ }^{6}$ WF Connell (1972) membedakan tujuh peran seorang guru yaitu (1) guru

${ }^{5}$ Abdul Mujib, Kepribadian dalam Psikologi Islam, (Jakarta: Rajawali Press, 2006), hlm. 109110.

${ }^{6} U U$ RI, No. 14 Tahun 2005 “Tentang Guru dan Dosen", Bab II, Pasal 2 Ayat 1.

${ }^{7}$ DR Ahmad Tafsir, Ilmu Pendidikan Dalam Perspektif Islam, Remaja Rosdakarya, Bandung (nurturer), (2) model, (3) pengajar dan pembimbing, (4) pelajar (learner), (5) komunikator terhadap masyarakat setempat, (6) pekerja administrasi, serta (7) kesetiaan terhadap lembaga. ${ }^{7}$

\section{B. Pengertian dan Fungsi Guru dalam Pendidikan}

1. Pengertian Guru dalam Pendidikan Menurut Undang-Undang SISDIKNAS Nomor 20 Tahun 2003 tentang Sistem Pendidikan Nasional pasal 39 ayat 2, yang menyatakan bahwa: "Pendidik adalah tenaga profesional yang bertugas merencanakan dan melaksanakan proses pembelajaran, melakukan bimbingan, dan pelatihan, serta melakukan penelitian dan pengabdian masyarakat, terutama bagi pendidik pada perguruan tinggi". 8

Makna guru (pendidik) sebagai mana dalam UUSPN No. 20 Tahun 2003, Bab I, pasal 1 ayat 6 adalah tenaga kependidikan yang berkualifikasi sebagai guru, dosen, konselor, pamong belajar, widyaiswara, tutor, instruktur, fasilitator, sebutan lain yang sesuai dengan kekhususannya, serta berpartisipasi dalam menyelenggarakan pendidikan. Dalam pengertian yang sederhana guru adalah orang yang memberikan ilmu pengetahuan kepada peserta didik. Guru dalam pandangan masyarakat adalah orang yang melaksanakan pendidikan di tempat-tempat tertentu tidak mesti di lembaga pendidikan formal, tetapi bisa juga di masjid, di surau atau musholla, di rumah, dan sebagainya. ${ }^{9}$ Pendidik atau guru adalah orang yang dengan sengaja mempengaruhi orang lain untuk mencapai tingkat kesempurnaan yang

${ }^{8}$ A. Fatah Yasin, Dimensi-Dimensi Pendidikan Islam, (Malang: UIN Malang Press, 2008), hlm. 71

${ }^{9}$ Zaenal, Strategi dan Metode Pembelajaran, (Pekalongan: Stain Pekalongan Press, 2013), hlm: 5 
lebih tinggi, status pendidik dalam model ini bisa diemban oleh siapa saja, dimana saja, dan kapan saja. ${ }^{10}$ Pendidikan adalah usaha sadar dan sistematis yang dilakukan oleh orang-orang yang diserahi tanggung jawab untuk mempengaruhi peserta didik agar mempunyai sifat dan tabiat sesuai dengan cita-cita pendidikan. Mendidik adalah membantu anak dengan sengaja (dengan jalan membimbing, membantu dan memberi pertolongan) agar menjadi manusia dewasa, bersusila, bertanggungjawab dan mandiri. Dalam proses pendidikan tersebut yang mengambil peran penting adalah pendidik/ guru. Disini pendidik sangat berpengaruh terhadap proses pendidikan siswa, sehingga di butuhkan pendidik yang berkualitas dalam proses pendidikan tersebut.

\section{Fungsi Guru perspektif pendidikan Islam}

Peran dan fungsi yang cukup berat untuk diemban ini tentu saja membutuhkan sosok seorang guru atau pendidik yang utuh dan tahu dengan kewajiban dan tanggung jawab sebagai seorang pendidik. Pendidik itu harus mengenal Allah dalam arti yang luas, dan rasul, serta memahami risalah yang dibawanya. ${ }^{11}$ Tugas seorang guru yang pertama dan terpenting adalah pengajar(murabbiy, mu'allim). Firman Allah dalam surat Ar-Rahman[55]: 2 - 4.

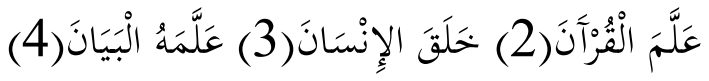

Yang telah mengajarkan Al Quran. Dia menciptakan manusia. Mengajarnya pandai berbicara.(QS. Ar-Rahman [55]: 24).

Guru adalah figur seorang pemimipin. Guru adalah sosok arsitektur yang dapat membentuk jiwa dan watak anak didik. Guru mempunyai kekuasaan dalam

${ }^{10}$ A. Fatah Yasin, Dimensi-Dimensi Pendidikan Islam, (Malang: UIN Malang Press, 2008), hlm. 68 membentuk dan membangun kepribadian anak didik menjadi orang yang berguna bagi nusa, bangsa dan agama. Guru bertugas menyiapkan manusia susila yang cakap yang dapat diharapkan membangun dirinya dan membangun bangsa dan negara. Seorang guru memiliki banyak tugas baik itu yang terkait oleh dinas maupun di luar dinas, dalam bentuk pengabdian. Apabila dikelompokkan terdapat tiga jenis tugas guru diantaranya:

a. Tugas guru sebagai profesi meliputi: mendidik, mengajar dan melatih

b. Tugas guru dalam bidang kemanusiaan di sekolah harus dapat menjadikan dirinya sebagai orang tua kedua bagi para siswanya

c. Tugas guru dalam bidang kemasyarakatan, di bidang ini guru mempunyai tugas mendidik dan mengajar masyarakat untuk menjadi warga negara Indonesia yang bermoral pancasila.

Tugas pendidik itu cakupannya sangat luas dan juga bertanggung jawab mengelola, mengarahkan, memfasilitasi, dan merencanakan serta mendesain program yang akan dijalankan, dari sini tugas dan fungsi pendidik dapat disimpulkan antara lain:

a. Sebagai pengajar (instructional), yang bertugas merencanakan program pengajaran dan melaksanakan program yang telah disusun serta mengakhiri

b. Sebagai pendidik (educator), yang mengarahkan peserta didik pada tingkat kedewasaan dan kepribadia "kamil" seiring dengan tujuan Allah menciptakannya

c. Sebagai pemimipin (managerial), yang memimpin, mengendalikan diri sendiri,

${ }^{11}$ Prof. DR. H. Ramayulis, Imu Pendidikan Islam, Jakarta: Kalam Mulia, hlm. 58 
peserta didik dan masyarakat yang terkait terhadap berbagai masalah yang menyangkut upaya pengarahan, pengorganisasian, pengontrolan dan partisipasi atas program pendidikan yang dilakukan.

Guru merupakan pendidik professional dengan tugas utama mendidik, mengajar, membimbing, mengarahkan, melatih, menilai, dan mengevaluasi peserta didik pada jalur pendidikan formal. Tugas utama itu akan efektif jika guru memiliki derajat profesionalitas tertentu yang tercermin dari kompetensi, kemahiran, kecakapan, atau keterampilan yang memenuhi standar mutu atau norma etik tertentu.

Dalam UU Republik Indonesia Nomor 14 Tahun 2005 disebutkan bahwa guru berfungsi untuk meningkatkan martabat dan peran guru sebagai agen pembelajaran berfungsi untuk meningkatkan mutu pendidikan nasional. Daoed Yoesoef (1980) menyatakan bahwa seorang guru mempunyai tiga tugas pokok yaitu tugas profesional, tugas manusiawi, dan tugas kemasyarakatan (sivic mission). Jika dikaitkan pembahasan tentang kebudayaan, maka tugas pertama berkaitan dengan logika dan estetika, tugas kedua dan ketiga berkaitan dengan etika. Tugas-tugas profesional dari seorang guru yaitu meneruskan atau transmisi ilmu pengetahuan, keterampilan dan nilai-nilai lain yang sejenis yang belum diketahui anak dan seharusnya diketahui oleh anak. Tugas manusiawi adalah tugas-tugas membantu anak didik agar dapat memenuhi tugastugas utama dan manusia kelak dengan

${ }^{12}$ Helyati Afrida, Peran Guru PAI dalam meningkatkan prestasi belajar siswa tentang pelajaran Agama di SDN Limus Nunggal 02 Cileungsi, (Jakarta: FITK UIN Jakarta, skripsi, 2012), hlm. 11 sebaik-baiknya. Tugas-tugas manusiawi itu adalah transformasi diri, identifikasi diri sendiri dan pengertian tentang diri sendiri.

Tugas kemasyarakatan merupakan konsekuensi guru sebagai warga negara yang baik, turut mengemban dan melaksanakan apa-apa yang telah digariskan oleh bangsa dan negara lewat UUD 1945 dan GBHN. Ketiga tugas guru itu harus dilaksanakan secara bersama-sama dalam kesatuan organis harmonis dan dinamis. Seorang guru tidak hanya mengajar di dalam kelas saja tetapi seorang guru harus mampu menjadi katalisator, motivator dan dinamisator pembangunan tempat di mana ia bertempat tinggal.

\section{Peranan guru perspektif pendidikan Islam}

Peranan adalah "lakon yang dimainkan oleh seorang pemain, peran dalam hal ini adalah pola tingkah laku tertentu yang merupakan ciri khas semua petugas dari pekerjaan atau jabatan tertentu. Peran artinya "Suatu bagian memegang pimpinan yang utama". ${ }^{12}$ Dalam Kamus Umum Bahasa Indonesia peranan merupakan "Bagian yang dimainkan oleh seorang pemain, ia berusaha bermain baik di semua yang dibebankan kepadanya atau tindakan yang dilakukan seseorang di suatu peristiwa". ${ }^{3}$ Peran adalah Perilaku, kewajiban, dan hak-hak yang melekat pada status". ${ }^{14}$ Peranan merupakan aspek dinamis kedudukan. Pembedaan kedudukan dengan peranan adalah untuk kepentingan ilmu pengetahuan. Keduanya tak dapat

\footnotetext{
${ }^{13}$ Departemen Pendidikan Nasional, Kamus Besar Bahasa Indonesia Pusat Bahasa,(Jakarta: Gramedia Pustaka Utama, 2012), cet. 4, hlm. 1051

${ }^{14}$ Komanto Sunarto, Sosiologi dengan Pendekatan Membumi, Terj. dari Essential of Sociology oleh James M. Henslin, (Jakarta: Erlangga, 2007), cet. 1, hlm. 95
} 
dipisah-pisahkan karena yang satu tergantung pada yang lain dan sebaliknya. ${ }^{15}$

Keberhasilan pelaksanaan belajar mengajar tergantung pada guru, sebab guru merupakan ujung tombak dalam proses pembelajaran. Banyak peran yang diperlukan guru sebagai pendidik atau siapa saja yang telah menerjunkan diri sebagai guru. Semua peranan yang diharapkan guru diantaranya:

a. Guru sebagai sumber belajar

b. Guru sebagai fasilitator

c. Guru sebagai pengelola pembelajaran

d. Guru sebagai demonstrator

e. Guru sebagai pembimbing

f. Guru sebagai motivator

g. Guru sebagai evaluator. ${ }^{16}$

Di samping memiliki kompetisi bidang pengetahuan yang menjadi disiplin ilmu dan profesionalitasnya seorang guru harus memiliki sifat-sifat pendidik yang baik, terutama oleh guru agama. Muhammad Athiyah Al-Abrasyi menyebutkan tujuh sifat yang harus dimiliki guru:

a. Seorang guru harus memiliki sifat zuhud yaitu tidak mengutamakan untuk mendapat materi dalam tugasnya, melainkan karena mengharapkan keridlaan Allah semata-mata.

b. Seorang guru memiliki jiwa yang bersih dari sifat dan akhlak yang buruk.

c. Seorang guru harus ikhlas dalam melaksanakan tugasnya

d. Seorang guru harus bersifat pemaaf terhadap muridnya.

${ }^{15}$ Soerjono Soekanto, Sosiologi Suatu Pengantar, (Jakarta: Grafindo Persada, 1982), hlm. 212

${ }^{16}$ Wina Sanjaya, Strategi Pembelajaran Berorientasi Standar Proses Pendidikan, Cet. II (Jakarta: Kencana Prenada Media Group, 2006), hlm. 20-31 e. Seorang guru harus dapat menempatkan dirinya sebagai seorang bapak, sebelum ia menjadi seorang guru.

f. Seorang guru harus mengetahui bakat, tabiat dan watak murid-muridnya.

g. Seorang guru harus menguasai bidang studi yang diajarkan. ${ }^{17}$

\section{Kedudukan dan Fungsi Guru perspektif pendidikan Islam}

Menurut al-Ghazali, tugas pendidik yang utama adalah menyempurnakan, membersihkan, menyucikan, serta mengajak mendekatkan diri kepada Allah SWT. Karena tujuan pendidikan Islam yang utama adalah upaya untuk mendekatkan diri kepada-Nya. ${ }^{18}$ Seeorang pendidik bukanlah bertugas memindahkan atau mentrasfer ilmunya kepada orang lain atau kepada anak didiknya. Tetapi pendidik juga bertanggungjawab atas pengelolaan, pengarah fasilitator dan perencanaan. Oleh karena itu, fungsi dan tugas pendidik dalam pendidikan dapat disimpulkan menjadi tiga bagian, yaitu: ${ }^{19}$

1. Sebagai instruksional (pengajar), yang bertugas merencanakan program pengajaran dan melaksanakan program yang telah disusun serta mengakhiri dengan pelaksanaan penilaian setelah program dilakukan.

2. Sebagai educator (pendidik), yang mengarahkan peserta didik pada tingkat kedewasaan dan berkepribadian kamil seiring dengan tujuan Allah SWT menciptakannya.

\footnotetext{
${ }^{17}$ Abuddin Nata, Filsafat Pendidikan Islam, (Jakarta: PT. Logos Wacana Ilmu, 2001), Cet ke-4, hlm. 70-76

${ }^{18} \mathrm{Abu}$ Hamid Muhammad al-Ghazali, Ihya 'Ulum al-Din, Terj. Ismail Ya'qub, (Semarang: Faizan, 1979), hlm. 65, 68, 70.

${ }^{19}$ Roestiyah NK, Masalah-masalah Ilmu Keguruan, (Jakarta: Bina Aksara, 1982), hlm. 86.
} 
3. Sebagai managerial (pemimpin), yang memimpin, mengendalikan kepada diri sendiri, peserta didik dan masyarakat yang terkait, terhadap berbagai masalah yang menyangkut upaya pengarahan, pengawasan, pengorganisasian, pengontrolan dan partisipasi atas program pendidikan yang dilakukan.

Selain tiga fungsi diatas, guru juga harus mampu memainkan metode dan teknik pengajaran yang menarik dan dapat memberikan motivasi kepada peserta didiknya. Beberapa metode dan teknik yang dicontohkan Rasulullah SAW, sebagaimana dikutif oleh, Dr. M. Syafii Antonio, M. Ec. ${ }^{20}$ dalam bukunya Muhammad SAW The Super Leader Super Manager menuliskan 20 metode dan teknik pengajaran sebagai 'Holistic learning methods' yang diambil dari sirah Rasullah SAW. Inilah 20 metode tersebut:

1. Learning conditioning, (meminta diam untuk mengingatkan, menyeru secara langsung dan perintah untuk menyimak dan diam dengan cara tidak langsung);

2. Active interacetion. (interaksi pendengeran: teknik berbicara, tidak bertele-tele pada ucapan dan tidak terlalu bernada puitis, memperhatikan intonasi, diam sebentar ditengah-tengah penjelasan; interaksi pandangan: eye contact dalam mengajar, memanfaatkan ekspresi wajah, tersenyum);

3. Applied-learning, (metode praktikum yang diterapkan oleh guru dan yang dilakukan oleh siswa);

4. Scanning and levelling, (memahami siswa secara individu sesuai tingkat kecerdasannya);

5. Discussion and feed-back, (metode yang logis dalam memberikan jawaban dan membuat contoh sederhana yang mudah dipahami);

6. Story telling (bercerita);

7. Analogy and case study, (memberikan perumpamaan dan studi kasus nyata disekitar kehidupan);

8. Teaching and motivating (meningkatkan gairah belajar dan rasa keingintahuan yang tinggi);

9. Body language, (membuat peyampaiannya bertambah terang, lebih pasti dan jelas; menarik perhatian pendengar dan membuat makna yang dimaksud melekat pada pikiran; mempersingkat waktu);

10. Picture and graph technology, (penjelasan diperkuat dengan gambar atau tulisan);

11. Reasoning and argumentation, (memngungkapkan alasan akan memperjelas sesuatu yang sulit dan berat agar dipahami oleh siswa);

12. Self reflection, (memberi kesempatan kepada siswa untuk mnjawab sendiri suatu pertanyaan agar siswa dapat mengoptimalkan kerja otak dan mengasah pikiran);

13. Affirmation and repetition, (pengulangan kalimat dan ucapan nama);

14. Focus and point basis, (menggunakan teknik berdasarkan rumusan-rumusan besar atau poin akan membantu siswa dalam menyerap ilmu dan menjaganya dari lupa);

15. Question and answer method, (teknik bertanya untuk menarik perhatian pendengar dan membuat pendengar siap terhadap apa yang akan disampaikan kepada);

\footnotetext{
${ }^{20}$ Muhammad SAW, The Super Leader Super Manager", 2009
} 
16. Guessing with question, (penting untuk memperkuat pemahaman dan memperbesar keingintahuan);

17. Encuraging student to ask, (guru memberikan kesempatan dan motivasi kepada siswa untuk berani mengajukan pertanyaan: bertanya dapat menghapus kebodohan serta memperbaiki pemahaman dan pemikiran menjadi alat evaluasi guru atas cara penyampaian pelajarannya);

18. Wisdom in answering question, (menyikapi orang-orang yang mengajukan pertanyaan sesuai dengan tingkat pengetahuannya; meyikapi si petanya dengan sikap yang bermanfaat baginya);

19. Commenting on student answer, (memberikan komentar terhadap jawaban siswa);

20. Honesty, (seorang guru harus menanamkan sikap mulia berani mengakui ketidaktahuan kedalam diri siswanya. Ucapan 'aku tidak tahu adalah bagian dari ilmu').

\section{Syarat dan Tanggung Jawab Guru perspektif pendidikan Islam}

\section{Syarat Guru}

Persyaratan guru menurut Prof. Dr Zakiah Darajat yang penulis kutip dari buku Guru dan Anak Didik dalam Interaksi Edukatif karya Drs. Syiful Bahri Djamarah, M.Ag adalah:
a. Takwa Kepada Allah SWT
b. Berilmu
c. Sehat Jasmani
d. Berkelakuan Baik. ${ }^{21}$

\section{Tanggung Jawab Guru}

${ }^{21}$ Syaiful Bahri Djamhara, Guru dan Anak Didik dalam Interaksi Edukatif, (Jakarta: Rineka Cipta, 2010), cet. 2 hlm. 32
Beberapa tanggung jawab guru terhadap murid yaitu:

a. Guru harus menuntut murid belajar

b. Turut membina kurikulum

c. Melakukan pembinaan terhadap diri siswa (kepribadian, watak, dan jasmaniah)

d. Memberikan bimbingan kepada murid

e. Melakukan diagnosis atas kesulitankesulitan belajar dan mengadakan penilaian atas kemajuan belajar

f. Menyelenggarakan penelitian

g. Mengenal masyarakat dan ikut serta aktif

h. Menghayati, mengamalkan, dan mengamankan Pancasila

i. Turut serta membantu terciptanya kesatuan dan persatuan bangsa dan perdamaian dunia.

j. Turut mensukseskan pembangunan

k. Tanggung jawab meninggkatkan peranan profesional guru. ${ }^{22}$

\section{E. Kompetensi Guru perspektif pendidikan Islam}

Standar Kompetensi guru dalam perspektif pendidikan Islam, yaitu meliputi: (1) Kompetensi Pedagogik; (2) Kompetensi personal (kepribadian), (3) Kompetensi sosial; dan (4) Kompetensi profsional. ${ }^{23}$

1. Kompetensi Pedagogik, yang meliputi:

a. Pemahaman wawasan dan landasan kependidikan.

b. Pemahaman terhadap peserta didik.

c. Pengembangan kurikulum.

d. Pelaksanaan pendidikan yang mendidik dan dialogis.

e. Perencanaan pembelajaran

f. Pemanfaatan tehnologi

${ }^{22}$ Syaiful Bahri Djamhara, Guru dan Anak Didik dalam Interaksi Edukatif, (Jakarta: Rineka Cipta, 2010), cet. 2 hlm. 36

${ }^{23}$ Sahertian, 1994, hlm. 56 
3. Kompetensi Personal-religius (kepribadian). meliputi:

a. Kepribadian yang mantap dan terkontrol.

b. Istiqomah/stabil

c. Dewasa (usia dan pendidikannya)

d. Arif dan bijaksana

e. Berwibawa

f. Uswah hasanah(Menjadi teladan yang baik)

g. Berakhlak mulia

h. Ihlash

i. Taqwa

j. Sabar (dalam mengajarkan ilmu)

k. Jujur

1. Adil.

4. Kompetensi Sosial-religius.

Kemampuan Sosial-religius bagi pendidik adalah menyangkut ajaran dakwah Islam, seperti: Sikap gotong royong, tolong menolong berkomunikasi dan bergaul secara efektif dan efesien, menjaga hubungan sekolah dengan masyarakat, peran guru di masyarakat, dan Sikap toleransi.

5. Kompetensi Profesional-religius.

Kemampuan ini menyangkut kemampuan untuk menjalankan tugas keguruannya secara profesional, dalam arti mampu membuat keputusan keahlian atas beragamnya kasus serta mampu mempertanggung jawabkan berdasarkan teori dan wawasan keahliannya dalam perspektif Islam. Seperti Mengetahui hal-hal yang perlu diajarkan, Menguasai keseluruhan bahan materi yang akan disampaikan pada anak didiknya, Mempunyai kemampuan menganalisis materi yang diajarkan dan menghubungkannya dengan kontek keseluruhan komponenkomponen secara keseluruhan melalui pola yang diberikan Islam tentang bagaimana cara berfikir (way of thinking) dan carahidup (way of life) yang perlu dikembangkan melalui proses edukasi, Mengamalkan terlebih dahulu informasi yang telah didapat sebelum disajikan pada anak didiknya, Mengevaluasi proses dan hasil pendidikanyang sedang dan sudah dilaksanakan, Memberi hadiah (tabsyir/reward) dan hukuman (tandzir/punishment) sesuai dengan usaha dan upaya yang dicapai anak didik dalam rangka memberikan persuasi dan motivasi dalam proses belajar.

Dalam Islam sebenarnya empat kompetensi tersebut sudah ada dalam diri Rasulullah SAW (QS. Al-Ahzab [33]: 21) sebagai seorang utusan Allah SWT. Jauh sebelum peraturan pemerintah dan undang undang tentang guru dibuat, maka islam telah mengajarkan bahwa dalam diri Rasulullah ada keteladanan yang diambil. Rasulullah sebagai pendidik pertama umat islam sepatutnya dicontoh dan diaplikasikan perilakunya dalam kehidupan sehari-hari. Jika kita mengacu pada peraturan undang undang tentang kompetensi guru, maka akan bisa ditarik benang merah bahwa empat kompetensi yang ada dalam undang undang tersebut sebenarnya ada pada sifat wajib yang dimiliki rasulullah, yaitu siddiq, amanah, tabligh, fathonah. Dalam perspektif Islam, mengemban amanat sebagai guru bukan terbatas pada pekerjaan atau jabatan seseorang, melainkan memiliki dimensi nilai yang lebih luas dan agung yaitu tugas ketuhanan, kerasulan dan kemanusiaan. Dikatakan sebagai tugas ketuhanan karena mendidik merupakan sifat "fungsional" Allah (sifat rububiyah) sebagai "Rabb" yaitu sebagai "guru" bagi semua makhluk. Allah mengajar semua makhluknya lewat tanda-tanda alam (sign), dengan 
menurunkan wahyu, mengutus rasul-Nya dan lewat hamba-hambanya. Allah memanggil hamba-hamba-Nya yang beriman untuk mendidik.

Guru yang efektif (effective teacher) adalah yang dapat menunaikan tugas dan fungsinya secara profesional. Untuk dapat melaksanakan tugas secara profesional diperlukan berbagai persyaratan seperti: kompetensi akademik, kompetensi metodologis, kematangan pribadi, sikap penuh dedikasi, kesejahteraan yang memadai, pengembangan karier, dan budaya kerja dan suasana kerja yang kondusif. Dalam pandangan Islam, disamping syarat-syarat di atas, seorang guru haruslah seorang yang bertaqwa, yaitu beriman, berilmu dan berakhlakul karimah sehingga tidak saja efektif dalam mengajar tetapi juga efektif dalam mendidik. Sebab mendidik dengan keteladanan lebih efektif dari pada mengajar dengan perkataan (lisan al-hal afshahu min lisan al-maqal).

\section{F. Penutup}

Kedudukan dan Peran Guru Dalam Pendidikan Islam, menyempurnakan, membersihkan, menyucikan, manusia untuk mendekatkan diri kepada Allah SWT. Tujuan pendidikan Islam adalah upaya mendekatkan diri kepada-Nya. Secara umum, pendidik adalah orang yang memiliki tanggung jawab untuk mendidik. Sementara secara khusus, pendidik dalam perspektif Islam adalah orang-orang yang bertanggung jawab terhadap perkembangan peserta didik, baik potensi afektif, kognitif, maupun psikomotorik sesuai dengan nilainilai ajaran Islam. Tanggung jawab seorang guru dapat dilihat dalam firman Allah: "Hai orang-orang yang beriman, peliharalah dirimu dankeluargamu dari api neraka".(Q.S. at-Tahrim: [6]; 3. Peran guru yaitu: (1) guru (nurturer), (2) model, (3) pengajar dan pembimbing, (4) pelajar (learner), (5) komunikator terhadap masyarakat setempat, (6) pekerja administrasi, serta (7) kesetiaan terhadap lembaga.

\section{DAFTAR PUSTAKA}

Al-Qur'an dan Terjemahannya, Departemen Agama RI, Bandung: CV Penerbit Diponegoro, 2007.

Abdul Mujib, Kepribadian dalam Psikologi Islam, Jakarta: Rajawali Press, 2006.

Abu Hamid Muhammad al-Ghazali, Ihya 'ulum al-Din, terj. Ismail ya'qub, Semarang: Faizan, 1979.

A. Fatah Yasin, Dimensi-Dimensi Pendidikan Islam, Malang: UIN Malang Press, 2008.

Helyati Afrida, Peran Guru PAI dalam meningkatkan prestasi belajar siswa tentang pelajaran Agama di SDN Limus Nunggal 02 Cileungsi, Jakarta: FITK UIN Jakarta, skripsi, 2012.

Departemen Pendidikan Nasional, Kamus Besar Bahasa Indonesia Pusat Bahasa, Jakarta: Gramedia Pustaka Utama, 2012, cet.4.

M. Athiyah al-Abrasyi, Dasar-dasr Pokok Pendidikan Islam, terj. Bustami A. Ghani, Jakarta: Bulan Bintang, 1987.

Muhammad Muntahibun Nafis, Ilmu Pendidikan Islam, Yogyakarta: Teras, 2011

Komanto Sunarto, Sosiologi dengan Pendekatan Membumi, Terj.dari Essential of Sociology oleh James M.Henslin, Jakarta: Erlangga, 2007,cet.1

Roestiyah NK, Masalah-masalah Ilmu Keguruan, Jakarta: Bina Aksara, 1982. 
Ramayulis, Dkk, Pendidikan Islam Dalam Rumah Tangga, Jakarta: Kalam Mulia, 2001.

Sudiyono, Ilmu Pendidikan Islam,Jakarta: Rineka Cipta, 2009.

Soerjono Soekanto, Sosiologi Suatu Pengantar, Jakarta: Grafindo Persada, 1982.

Syaiful Bahri Djamhara, Guru dan Anak Didik dalam Interaksi Edukatif, Jakarta: Rineka Cipta, 2010.
Tafsir, Ahmad, Dr, Ilmu Pendidikan Dalam Perspektif Islam, Remaja Rosdakarya, Bandung

UU RI, No 14 Tahun "Tentang Guru dan Dosen", Bab II, Pasal 2 Ayat 1. 2005.

Wina Sanjaya, Strategi Pembelajaran Berorientasi Standar Proses Pendidikan, Cet. II Jakarta: Kencana Prenada Media Group, 2006.

Zaenal, Strategi dan Metode Pembelajaran, Pekalongan: STAIN Pekalongan Press, 2013. 
Kedudukan dan Peran Guru dalam Perspektif Pendidikan Islam

Rausyan Fikr. Vol. 14 No. 1 Maret 2018. ISSN. 1979-0074 e-ISSN. 9772580594187 | 2 